\title{
Effects of Summer Pruning and Cropload on Summer and Winter Bud Carbohydrates in Sweet Cherry
}

\author{
Penelope F. Measham ${ }^{1}$ \\ Tasmanian Institute of Agriculture, University of Tasmania, Private Bag 98, TAS, Australia
}

Audrey G. Quentin

CSIRO Ecosystems Science, Private Bag 12, TAS, Australia

\author{
Nicholas MacNair \\ Tasmanian Institute of Agriculture, University of Tasmania, Private Bag 98, TAS, Australia
}

\begin{abstract}
Additional Index words. bud burst, fruit quality, Prunus avium
ABSTRACT. Orchard management practices have the potential to influence carbohydrate supply to storage organs, including buds. This study was designed to assess if bud carbohydrates could be manipulated by orchard practices in sweet cherry (Prunus avium). Additionally, we investigated the impact of any such changes on subsequent bud burst and fruit quality the next season. We examined the effect of pruning at different fruit growth stages and cropload on summer and winter bud non-structural carbohydrates (NSCs) and on fruit quality at harvest the next summer in two cultivars. Buds were collected postharvest in summer and after the onset of dormancy in winter, and individual soluble sugars and starch were extracted. The next growing season, flower number and fruit set were recorded. When fruit reached full maturity, fruit were harvested for quality assessment. We observed qualitative changes in NSCs from buds collected in summer and winter. Pruning significantly reduced available NSCs in late summer buds but made little difference by winter; only early pruning showed slight changes in sucrose and glucose. However, early pruning positively influenced the next season's fruit grade. High cropload resulted in higher NSCs in winter buds than the low cropload. Significant changes in sucrose from summer to winter were observed, and levels of sucrose in the buds differed between cultivars. Different levels of winter bud sucrose between cultivars corresponded to different rates of bud burst. Although pruning was able to manipulate NSCs in buds within a few weeks, these changes were not sufficient to influence the rate of bud burst within a cultivar, but pruning did influence fruit quality in the next season.
\end{abstract}

Sweet cherry production relies on the availability of stored nonstructural carbohydrates to support and maintain growth (Flore and Layne, 1999). Throughout the growing season, carbohydrate concentrations fluctuate, corresponding to seasonal phenology (Gent and Seginer, 2012). The efficiency in producing, transporting, using, and storing of carbohydrates significantly influences the growth rate and quality of both vegetative and reproductive organs (Clair-Maczulajtys et al., 1994). In the period leading up to dormancy, fruit trees will accumulate total NSCs, which are then translocated into storage areas including buds, trunk, and roots (Gaudillère et al., 1992; Loescher et al., 1990). NSCs play an essential role in initiating and maintaining growth (Flore and Layne, 1999; Keller and Loescher, 1989; Maust et al., 2000; Rady and Seif El-Yazal, 2013) during periods of stress (such as dormancy, the breaking of dormancy, and initial stages of bud burst). In many fruit trees, including sweet cherry, flower buds develop earlier than vegetative buds; therefore, bud NSC reserves are critically important in initiating bud burst and must be sufficient or remobilized from other storage organs (Ben Mohamed et al., 2012; Cerasoli et al., 2004; Marafon et al., 2011; Richardson et al., 2010; Vasudevan et al., 1998) until photosynthetic leaf area can provide adequate photosassimilate to developing sinks (Dejong and Grossman, 1995; Flore and Layne, 1999).

Carbohydrate dynamics have been widely investigated at the whole-tree scale (Kozlowski, 1992; Lacointe et al., 1993). In

Received for publication 27 Sept. 2013. Accepted for publication 6 May 2014. ${ }^{1}$ Corresponding author. E-mail: Penelope.Measham@utas.edu.au. contrast, less is known about the fine-scale carbohydrate dynamics during winter dormancy in and around the meristematic zone within buds (Bonhomme et al., 2005). However, studies addressing this are becoming more frequent with recent work in grape (Vitis vinifera), pear (Pyrus pyrifolia), apple (Malus $\times$ domestica), and kiwifruit (Actinidia deliciosa) (Ben Mohamed et al., 2010; Ito et al., 2012; Rady and Seif El-Yazal, 2013; Richardson et al., 2010). Carbohydrate availability in these structures is of major importance to the control of bud growth and development during dormancy and dormancy release (Ben Mohamed et al., 2012; Marquat et al., 1999). A pivotal paper (Marquat et al., 1999) showed that the sucrose stored in buds of peach (Prunus persica) was used during dormancy release to synthesize the sorbitol and raffinose that are required for bud burst.

Concentration and mobilization of carbohydrates such as sugars and starches within tissues are affected by biotic and abiotic factors (Daie, 1985). Strategic pruning is important for optimizing relationships among shoot growth, source leaf area, current photosynthesis, annual building of storage reserves, and ultimate realization of good yields with high-quality fruit (Costes et al., 2006; Lang, 2001). Pruning, like all stresses, induces hydrolysis of reserves on one hand and an accumulation of certain metabolites on the other (Clair-Maczulajtys et al., 1994; Daie, 1985). Timing and severity of pruning can play a crucial role in the partitioning of the carbohydrate reserves. Early summer pruning can stimulate the reallocation of reserves to renewing leaf growth, whereas late summer pruning may reduce leaf demand. Late pruning has been shown to increase assimilates to 
the current season's sweet cherry fruit (Measham et al., 2013), which, at this time, is at maximum sink strength (Ayala and Lang, 2008; Flore and Layne, 1999).

Cropload (or simply the number of fruit per tree) can also influence fruit sugars in the current season (Bound et al., 2013; Measham et al., 2012; Roper et al., 1988). Klages et al. (2001) found a decrease in starch and an increase in glucose in apple fruit from trees with low croploads, whereas Roussos et al. (2011) found a decrease in glucose in apricot (Prunus armeniaca) fruit from low-cropping trees but no impact on total soluble solids. The impact of cropload on sweet cherry fruit quality appears to be a complex issue with inconsistent results, which may be explained partly by tree architecture (Bound et al., 2013). Manipulating cropload can additionally encourage bud development and flowering for the next season (Proebsting and Mills, 1981; Smith et al., 2007). Therefore, carbohydrates are posited as influencing flower bud differentiation, fruit set, and fruitlet abscission (Bustan et al., 2011) and fruit. However, a thorough investigation of varying carbohydrate concentration in developing buds and subsequent impact on the next phenological stages such as flowers, fruit set, and fruit has not occurred.

To better determine whether it is possible to improve bud burst through use of standard orchard practices to manipulate bud reserves of carbohydrate, and ultimately improve fruit yield and quality (Usenik et al., 2008; Vitasse et al., 2011), carbohydrate levels of buds were ascertained under different pruning regimes. The aim of this study was to determine the effect of pruning treatments (applied at different phenological stages) and cropload on the starch and soluble sugar contents of buds predormancy (summer) and during dormancy (winter) and fruit quality at harvest (the next summer). In addition, the impact of any resultant changes in bud carbohydrates during dormancy on bud burst (spring) was investigated.

\section{Material and Methods}

\section{Site and plant material}

Field trials were conducted in a commercial sweet cherry orchard in Plenty, southern Tasmania, Australia (lat. 42 $71^{\prime} \mathrm{S}$, long. $146^{\circ} 90^{\prime}$ E) from Stage II of fruit development in Nov. 2011 to the onset of dormancy in June 2012. The mean daily minimum and maximum temperature, during the next dormant winter period (June to August), was 2.5 and $12.7^{\circ} \mathrm{C}$, respectively. This region experienced a mean annual rainfall of $574 \mathrm{~mm}$. Two cultivars (Kordia and Sweetheart) were selected because it was observed that the two differed in time and rate of bud burst (Measham et al., 2014) and that they have differing growth habits. Trial trees were mature (15 years) and trained in a bush system on Mazzard rootstock and irrigated using microsprinklers scheduled according to soil moisture monitored by gypsum blocks. Trees were grown on wind-blown sands and dermasols.

\section{Trial design}

Two field trials were designed to explore bud carbohydrate dynamics during dormancy and investigate relationships between bud carbohydrates and subsequent fruit quality. Pruning treatments were used in an attempt to manipulate bud carbohydrate levels. Bud carbohydrate levels were additionally assessed from trees supporting different croploads. Fruit quality at harvest maturity was assessed in both trials.

Expt. 1: Summer Pruning. Pruning treatments were applied during the growing season of 2011-12 at different stages of fruit development (Stage II, Stage III, and postharvest). Pruning consisted of complete removal of the current season's extension growth. Timing and amount of pruning are given in Table 1; timing of pruning occurred from Stage II of fruit growth determined by visible assessment of pit hardening and then during Stage III of fruit growth in relation to harvest, either weeks before harvest (WBH) or weeks after harvest (WAH). Five trees of each cultivar were randomly assigned for each pruning treatment in a complete randomized block design.

Expt. 2: Cropload. Cropload [fruit per square centimeter trunk cross-sectional area (TCSA)] was calculated from 60 trees of each cultivar as per Measham et al. (2012) using whole-tree fruit number and trunk diameter to identify trees with croploads greater than seven fruit $/ \mathrm{cm}^{2}$ TCSA and less than four fruit $/ \mathrm{cm}^{2}$ TCSA. Five trees from these groups were then randomly selected and assigned as either high or low cropload. No cropload manipulations were assigned because it was a naturally low cropping year.

\section{Bud collection}

Bud collection from both trials occurred postharvest during the summer period (Feb. 2012, 2 weeks after harvest and before any leaf senescence) and after the onset of dormancy during winter (June 2012). Six buds per tree were randomly selected from each trial tree, placed into a paper bag, and then freeze-dried at $-110^{\circ} \mathrm{C}$ for a period of $48 \mathrm{~h}$. Once dried, the bags were stored in sealed containers in a freezer until processing.

Phenological data. Bud burst was calculated from visual assessments of each bud on five replicate 2-year-old samples from each replicate tree. Bud burst was calculated as the maximum percentage of buds showing a green side. Mean time to complete $50 \%$ bud burst was calculated as follows: $\mathrm{MTB}=\Sigma\left(t_{x} \times n_{x}\right) / \Sigma n$; where MTB is mean time of bud burst, $t_{x}$ is the time in days, staring from Day 0 , the day of buds showing side green, $n_{x}$ is the number of buds completing bud burst on days $x$, and $\mathrm{n}$ is the total number of buds bursting.

\section{Bud carbohydrate analysis and identification of individual sugars}

In preparation for carbohydrate analysis, two different grinding methods were used as a result of the size of sample material to collect uniform powder across all samples. Summer buds were

Table 1. Timing of pruning treatments during the growing season of 2011-12 in southern Tasmania at different stages of sweet cherry fruit development: Stage II of fruit growth, Stage III of fruit growth [3 and 1 week(s) before harvest (WBH)], and postharvest (1 week after harvest), and the amount of leaf material removed from sweet cherry trees at each pruning time.

\begin{tabular}{lccr}
\hline Pruning treatment & Stage of fruit development & Timing & Leaf material removed [mean \pm SE $(\mathrm{g})]$ \\
\hline Early & Stage II & Mid-Nov. 2011 & $1583 \pm 191$ \\
Mid & Stage III (3 WBH) & Late Dec. 2011 & $1634 \pm 158$ \\
Late & Stage III (1 WBH) & Early Jan. 2012 & $1768 \pm 163$ \\
Postharvest & Postharvest & Late Jan. 2012 & $2321 \pm 256$ \\
\hline
\end{tabular}


ground using a mortar and pestle before passing through a 1-mmmesh sieve. Winter buds were ground for $45 \mathrm{~s}$ using an analytical mill (A11; IKA, Selangor, Malaysia) and then passed through a 1-mm-mesh sieve. Therefore, all resultant samples were in fine powder form. Between each sample, the equipment was cleaned with ethanol to avoid cross-contamination. Approximately $100 \mathrm{mg}$ of dried bud samples were weighed into $10-\mathrm{mL}$ conical plastic test tubes for analysis. Soluble sugars (SS) were extracted from $100 \mathrm{mg}$ of dried bud tissue in $3 \mathrm{~mL}$ of $80 \%(\mathrm{v} / \mathrm{v})$ ethanol in a $60{ }^{\circ} \mathrm{C}$ water bath. After centrifugation $\left(10 \mathrm{~min}, 4000 \mathrm{~g}_{\mathrm{n}}, 4^{\circ} \mathrm{C}\right)$, the supernatant was collected into a plastic tube. The plug was extracted twice more. Supernatants were pooled and brought to a final volume of $9 \mathrm{~mL}$ with $80 \%$ ethanol. Both supernatant and residue plug were then frozen for later analysis. Starch (St) in the remaining plugs was then enzymatically (amyloglucosidase) reduced to glucose using a starch kit (Megazyme; Sigma-Aldrich, St. Louis, MO).

SS extracts were separated into their component peaks by injecting $25 \mu \mathrm{L}$ of each sample into an ultra-performance liquid chromatograph (Waters, Milford, MA) equipped with a pulsed amperometric detector and a CarboPac PA1 pellicular resin column ( 4 × $250 \mathrm{~mm}$; Dionex, Victoria, Australia). Fructose, glucose, and sucrose were quantified from peak area calculations related to regression curves of a trehalose standard. Total soluble sugar (TSS) was expressed as the sum of each individual SS. The concentration in St was determined colorimetrically at $510 \mathrm{~nm}$ using a spectrophotometer (WPA LightwaveS2000; Biochrom, Cambridge, U.K.). Total NSCs were expressed as a sum of TSS and starch. All carbohydrates are expressed in milligrams per gram on a dry weight (DW) basis.

\section{Flower and fruit assessment}

In the growing season (2013), flower number and fruit set were assessed from the same trees. Fruit set was calculated as the number of fruit compared with the original number of flowers and expressed as a percentage. Flowers were counted at full bloom and fruit counted 3 weeks before harvest.

When fruit reached full maturity (commercial harvest-ready) on 3 and 9 Jan. 2013 for 'Kordia' and 'Sweetheart', respectively, a minimum of 100 fruit from five experimental branches were harvested and transported on ice to the laboratory for quality assessment: weight, diameter, color, and fruit flesh firmness. A subsample of 25 blemish-free fruit was assessed from each replicate tree. Fruit diameter at the widest point and fruit height were measured using digital vernier calipers. Skin color was assessed using the Center Technique Interprofessionnel des Fruits et Légumes (CTIFL, Paris, France) color chart developed for cherries. Fruit firmness was assessed using a FirmTech II Fruit-Firmness Tester (Bio Works, Wamego, KS).

\section{Data analysis}

The relative changes in bud carbohydrates were calculated as the difference between winter and summer bud carbohydrates divided by summer bud carbohydrates. The effect of cultivar and treatments (pruning or cropload) on MTB, specific sugars in summer and winter buds, flower number, fruit set, and quality parameters were analyzed using two-way analysis of variance. Linear regression analyses were used to explore the relationships between winter bud carbohydrate concentrations, trunk diameter, and bud carbohydrates. All statistical analyses were performed in GenStat 14th (VSN International, Hemel Hempstead, U.K.). Differences between means were considered significant at $P<0.05$ using a $t$ test. Unless otherwise specified, all results quoted as significant are at probability level of 0.05 .

\section{Results}

EFFECT OF PRUNING ON SUMMER AND WINTER BUD CARBOHYDRATES. TSS concentration (mean $\pm \mathrm{SE}$ ) in summer buds was high $\left(8.14 \pm 0.98 \mathrm{mg} \cdot \mathrm{g}^{-1} \mathrm{DW}\right)$ compared with the concentration of starch $\left(4.32 \pm 0.43 \mathrm{mg} \cdot \mathrm{g}^{-1} \mathrm{DW}\right)$. The amount of sucrose in summer buds was low $\left[0.32 \pm 0.05 \mathrm{mg} \cdot \mathrm{g}^{-1} \mathrm{DW}\right.$ ( $4 \%$ of TSS)] compared with fructose $\left[4.87 \pm 0.58 \mathrm{mg} \cdot \mathrm{g}^{-1} \mathrm{DW}(60 \%\right.$ of TSS $\left.)\right]$ and glucose $\left[2.96 \pm 0.36 \mathrm{mg} \cdot \mathrm{g}^{-1} \mathrm{DW}(36 \%\right.$ of TSS $\left.)\right]$. Timing of pruning significantly affected TSS concentration in summer buds (Fig. 1A). For all individual SS, summer buds from trees left unpruned had the highest concentrations followed by trees pruned after harvest (1 WAH) (Fig. 1A). Early pruning (Stage II) and pruning at 3 and $1 \mathrm{WBH}$ resulted in comparatively low concentrations (Fig. 1A). It was also observed when collecting summer buds that trees from the early pruning treatment (Stage II) had experienced renewal extension growth, whereas trees from the remaining pruning treatments had not.

By dormancy, sucrose was high in winter buds $[25.60 \pm 0.95$ $\mathrm{mg} \cdot \mathrm{g}^{-1} \mathrm{DW}(74 \%$ of TSS)] compared with fructose $[5.62 \pm 0.09$ $\mathrm{mg} \cdot \mathrm{g}^{-1} \mathrm{DW}(16 \%$ of TSS $\left.)\right]$ and glucose $\left[3.3 \pm 0.07 \mathrm{mg} \cdot \mathrm{g}^{-1} \mathrm{DW}\right.$ ( $10 \%$ of TSS)]. In contrast to the summer buds, the timing of pruning had less effect on TSS concentration of winter buds. Early pruning (Stage II) showed lower concentrations of sucrose and glucose but higher glucose (Fig. 1B).

Neither cultivar nor the pruning treatments nor their interaction had a significant effect on starch concentration in summer buds (Table 2). Cultivar had a significant influence on summer bud SS $(P<0.001)$ with higher concentrations in buds of 'Sweetheart' than those of 'Kordia' (Table 2). Similarly, there was a significant difference between the two cultivars in carbohydrate concentrations in the winter buds, but individual SS concentrations varied (Table 2). Winter buds of 'Sweetheart' had higher fructose, glucose, and starch compared with buds of 'Kordia' (Table 2). However, sucrose, TSS, and NSC were significantly higher in 'Kordia' than in 'Sweetheart' (Table 2).

The relative changes in bud carbohydrate concentrations from summer to winter varied greatly between the different sugars. The greatest changes occurred in sucrose (Fig. 2A), followed by fructose (Fig. 2B) and glucose (Fig. 2C), and finally starch (Fig. 2D). The degree of change also varied between the two cultivars for each individual sugar. Overall changes in bud carbohydrate concentration varied substantially in 'Kordia'; in comparison, it was almost insignificant in 'Sweetheart'. In 'Kordia', timing of pruning affected the degree of change within each sugar (Fig. 2). The greatest increase in bud SS concentrations was recorded in the early pruning treatments (Stage II and $3 \mathrm{WBH}$ ) with lower changes in the late pruning treatments (1 WBH and $1 \mathrm{WAH})$.

EFfect of PRUNing and NSCs on BUd Burst. Pruning treatments did not significantly influence rate of bud burst. There was no significant effect of pruning or its interaction with cultivar on MTB. Across cultivars there was a significant positive relationship between concentration in sucrose of winter buds and MTB (Fig. 3). 'Kordia' buds had higher levels of sucrose than 'Sweetheart' buds. Neither the timing of the pruning nor the interaction cultivar $\times$ pruning affected the relationships. Additionally, we found that sucrose concentration of winter buds was significantly, and positively, related to the number of buds per spur, and the number of flowers per bud and per tree, in spring 

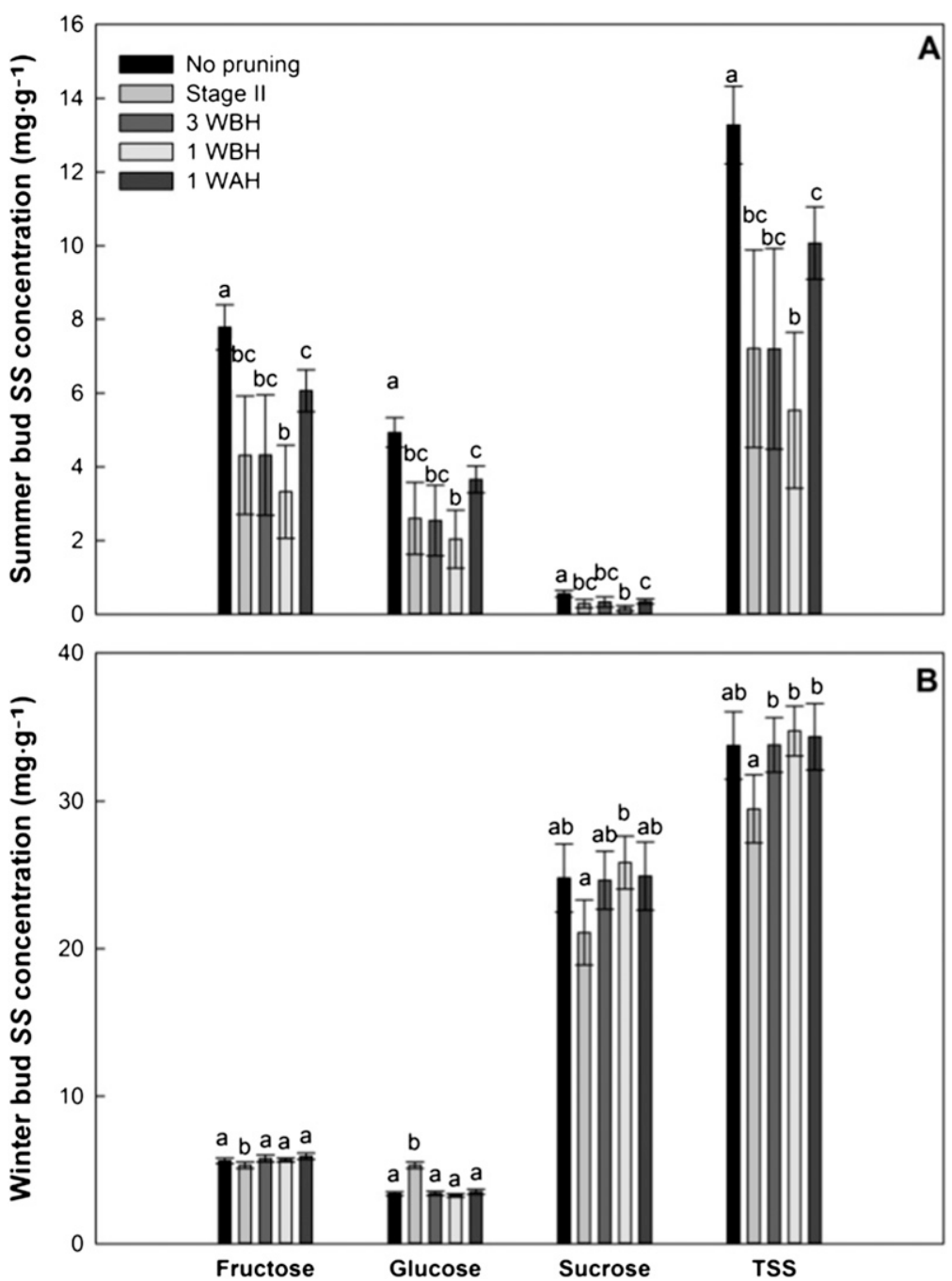

Fig. 1. Mean soluble sugar (SS) concentrations of fructose, glucose, sucrose, and total soluble sugars (TSS) in sweet cherry buds subjected to pruning treatment at Stage II of fruit growth, Stage III of fruit growth [3 and 1 week(s) before harvest (WBH)], and postharvest [1 week after harvest (WAH)]. Pruning treatment was applied during the 2011-12 season on two sweet cherry cultivars in southern Tasmania. Buds were collected in summer [A (Feb. 2012)] and winter [B (June 2012)]. Values are means of 10 replicates \pm SE. Treatment groups followed by the same letter did not differ statistically significantly from each other $(P>0.05)$ using Student's $t$ test.

although these relationships remained weak $\left(R^{2}<0.40\right)$. The significant factor in number of buds was cultivar.

EFFECT OF PRUNING ON THE NEXT SEASON's FRUIT QUALITY. 'Sweetheart' always produced heavier, bigger, and firmer fruit than 'Kordia' (Table 3). There was a significant $(P<0.001)$ interaction between cultivar and pruning treatments for weight, height, color, and firmness (Table 3). However, the effects of pruning were similar within each cultivar. Within 'Kordia', heavier, bigger, and darker fruit were produced when trees were left unpruned (control) or pruned early (Stage II) in the previous season. Within 'Sweetheart', heavier, bigger, and darker fruit were produced only when trees were pruned early (Stage II). Firmness values extended over a wide range with firmer fruit when trees were pruned early (Stage II) or late (1 WBH and 1 WAH) compared with no pruning or pruning $3 \mathrm{WBH}$ (Table 3 ). Calculated mean cropload for 'Kordia' and 'Sweetheart' at harvest were 10 and 14 fruit $/ \mathrm{cm}^{2}$ TCSA, respectively.

EFFECT OF CROPLOAD ON BUD CARBOHYDRATES. No significant interactions of cultivar $\times$ cropload effects on any sugars were found (Table 4). There were significant main effects of both cultivar and cropload on winter bud carbohydrate concentrations (Table 4); however, the effect varied depending on carbohydrate type. Cultivar had a significant effect on fructose, glucose, and sucrose with higher sucrose but lower fructose and glucose in 'Kordia' than 'Sweetheart' (Table 4). Low croploads resulted in significantly lower fructose, starch, and NSC concentrations than in the high cropload treatment (Fig. 4).

EFFECT OF CROPLOAD AND NSCS ON BUDS. Cropload had a significant effect on the numbers of spurs and flower buds per tree in the next season. Low cropload trees produced higher number of spurs and buds per tree (174 \pm 16 and $651 \pm 76$, respectively) in spring than the high cropload trees (112 \pm 13 and $456 \pm 70$, respectively). Cultivar only significantly affected the number of buds per tree with higher number of buds per tree in 'Kordia' (666 \pm 78$)$ than in 'Sweetheart' (442 \pm 63). Additionally, bud NSC concentrations were significantly related to the number of buds per tree. In this trial, fructose, glucose, and starch were negatively correlated with the number of buds per tree, although these relationships were weak $\left(R^{2}<0.40\right)$.

There were significant relationships between trunk diameter and bud SS concentrations (Fig. 5). Trunk diameter was recorded to calculate TCSA and was related positively to fructose and sucrose bud concentration in 'Kordia' only (Fig. 5A-B). Cropload did not affect these relationships.

\section{Discussion}

This study was designed to assess if bud carbohydrates could be manipulated by orchard practices in sweet cherry. Additionally, the impact of any such changes in bud carbohydrates on bud burst and fruit quality the next season was assessed. The practices chosen (pruning and cropload) had the potential to alter source:sink relationships and are readily applicable in commercial orchards. Summer pruning is a commonly used practice to control canopy size and vigor by improving light penetration through the canopy. The physiological significance of pruning has been well established. Pruning can stimulate photosynthesis and affect carbohydrate allocation as a result of the increased sink demand (Pinkard and Beadle, 1998) and increased light levels (Seginer and Gent, 2012). Pruning aims to manipulate the source and sink relations, which ultimately affect NSC accumulation and partitioning between the different perennial sinks (Lang, 2001; Layne and Flore, 1995; Usenik et al., 2008).

In this study, summer pruning of extension growth reduced available NSCs in late summer buds. High sink demand by fruit (Ayala and Lang, 2008) may have been competing with the sink demand for bud development for photoassimilates late in the fruit growing season. This also confirms that major accumulation of reserve carbohydrate in the bud predominantly occurs 
Table 2. Effect of cultivar on bud non-structural carbohydrate concentrations in the pruning experiment determined using analysis of variance. ${ }^{\mathrm{z}}$

\begin{tabular}{|c|c|c|c|c|c|c|}
\hline & Fructose & Glucose & Sucrose & TSS & Starch & NSC \\
\hline & \multicolumn{6}{|c|}{$\left[\right.$ mean $\left.\pm \mathrm{sE}\left(\mathrm{mg} \cdot \mathrm{g}^{-1} \mathrm{DW}\right)\right]$} \\
\hline \multicolumn{7}{|l|}{ Summer } \\
\hline Kordia & $4.74 \pm 0.34$ & $2.65 \pm 0.18$ & $0.17 \pm 0.03$ & $7.56 \pm 0.55$ & $1.94 \pm 0.56$ & $9.49 \pm 0.92$ \\
\hline Cultivar & $* * *$ & $* * *$ & $* * *$ & $* * *$ & NS & $* * *$ \\
\hline Treatment & $* *$ & $* *$ & $* *$ & $* *$ & NS & NS \\
\hline \multicolumn{7}{|l|}{ Winter } \\
\hline Kordia & $5.31 \pm 0.16$ & $3.06 \pm 0.12$ & $29.04 \pm 1.41$ & $37.41 \pm 1.61$ & $5.31 \pm 0.11$ & $42.72 \pm 1.62$ \\
\hline Sweetheart & $5.93 \pm 0.12$ & $3.53 \pm 0.09$ & $22.16 \pm 1.34$ & $31.62 \pm 1.34$ & $6.16 \pm 0.22$ & $37.77 \pm 1.24$ \\
\hline Cultivar & $* *$ & $* *$ & $* * *$ & $* * *$ & $* * *$ & $* * *$ \\
\hline
\end{tabular}

${ }^{\mathrm{z} B u d}$ collections were conducted in southern Tasmania in summer (Feb. 2012) and winter (June 2012) in two sweet cherry cultivars, Kordia and Sweetheart.

TSS = total soluble sugars, expressed as a sum of fructose, glucose, and sucrose; NSC = total non-structural carbohydrates, expressed as a sum of TSS and starch; DW = dry weight.

$* * * P<0.001 ; * * P<0.05 ; \mathrm{NS}=$ nonsignificant.
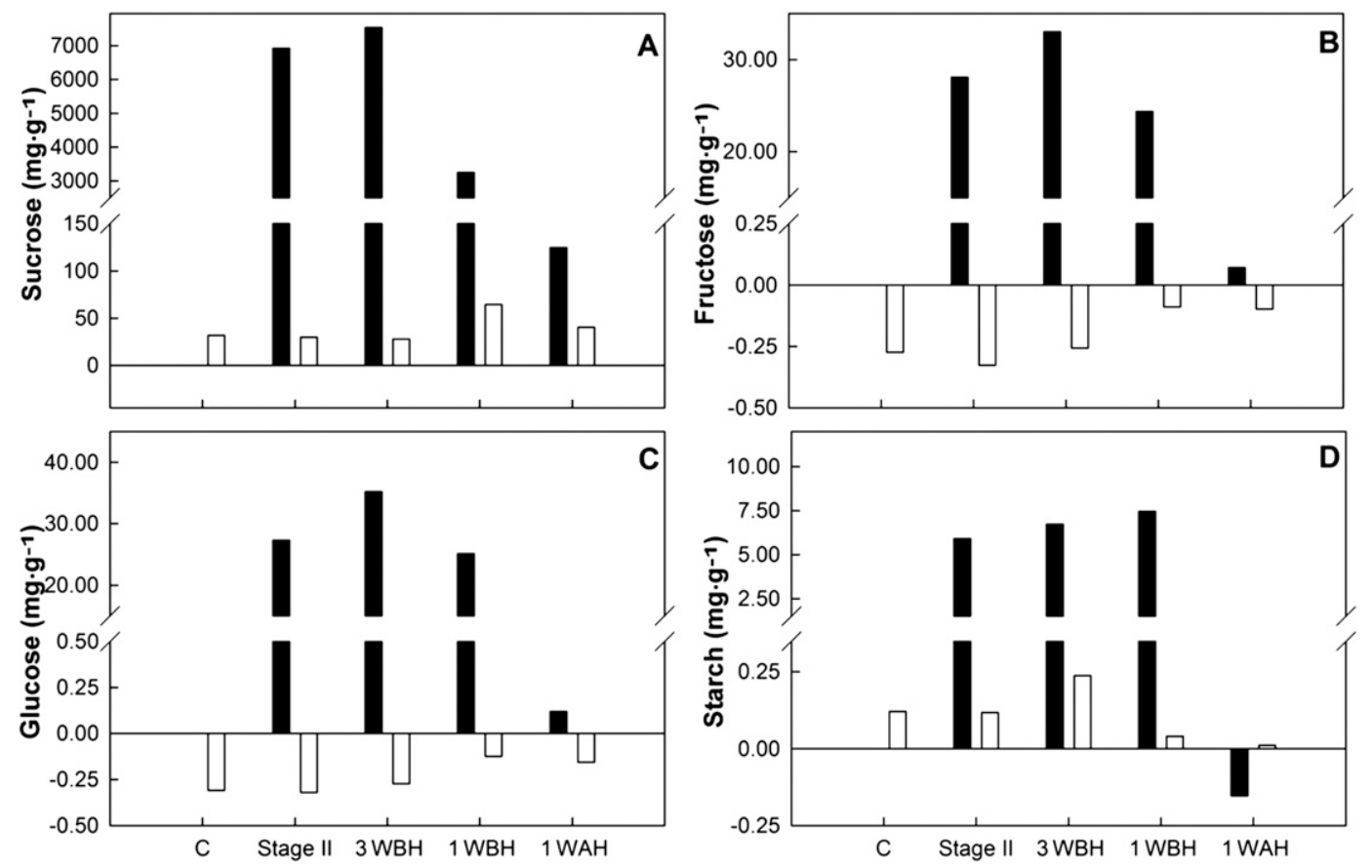

Fig. 2. Relative changes from summer to winter in sweet cherry bud carbohydrate concentrations of sucrose (A), fructose (B), glucose (C), and starch (D) for 'Kordia' (black bars) and 'Sweetheart' (white bars) subjected to pruning treatment at Stage II of fruit growth, Stage III of fruit growth [3 and 1 week(s) before harvest (WBH)], and postharvest [1 week after harvest (WAH)], and in control no pruning $(\mathbf{C})$ treatment. Degree of change varied between cultivars with greater changes in 'Kordia' than 'Sweetheart'.

later in the season, after harvest during leaf fall (Kapp, 2008; Keller and Loescher, 1989, Marquat et al., 1999).

We further observed changes in carbohydrate levels from buds collected in summer and winter. Relative concentrations of SS and starch also varied between summer and winter. The percentage of SS present in the buds increased from summer to winter, whereas starch remained stable, declining only slightly under the late pruning treatment. Keller and Loescher (1989) reported higher stored NSCs at leaf fall (winter) than spring. Starch can be converted into sucrose through amylase activity during the winter period resulting in peak sucrose levels (Bonhomme et al., 2005; Marafon et al., 2011; Marquat et al., 1999), which would then be resynthesized, reducing sucrose levels again in spring and subsequently hydrolyzed to support 


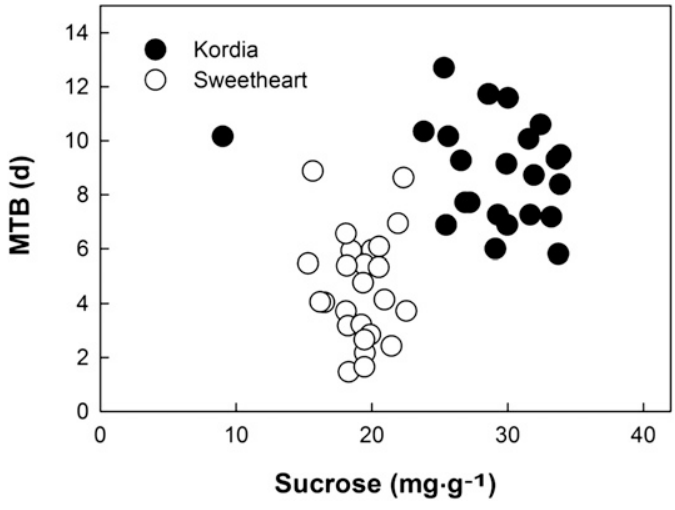

Fig. 3. Mean time of bud burst (MTB) in sweet cherry in the spring as a function of bud sucrose concentration in the preceding winter for 'Kordia' (black dots) and 'Sweetheart' (white dots). spring growth (Essiamah and Eschrich, 1985). This pattern was confirmed in our study where sucrose was barely detectable in summer but was the most predominant SS in winter.

Pruning had little effect on winter bud carbohydrate concentration. This observation supports the proposition that remobilization of carbohydrates at leaf fall was primarily directed toward buds, which may have been to the detriment of other perennial tissues. Only early pruning during Stage II of fruit growth reduced TSS, which further suggests that trees pruned early in the fruit growing season shift resource allocation to renewing leaf growth rather than bud development.

At bud burst, NSC reserves provide the carbon needed for growth until leaves can provide enough assimilate to meet the demand of reproductive and vegetative organs (Flore and Layne, 1999; Vasudevan et al., 1998). Our results showed a cultivar difference in winter bud sucrose levels: 'Kordia' buds

Table 3. Effect of cultivar (Kordia and Sweetheart) and pruning on sweet cherry fruit quality parameters determined using two-way analysis of variance. $^{\mathrm{z}}$

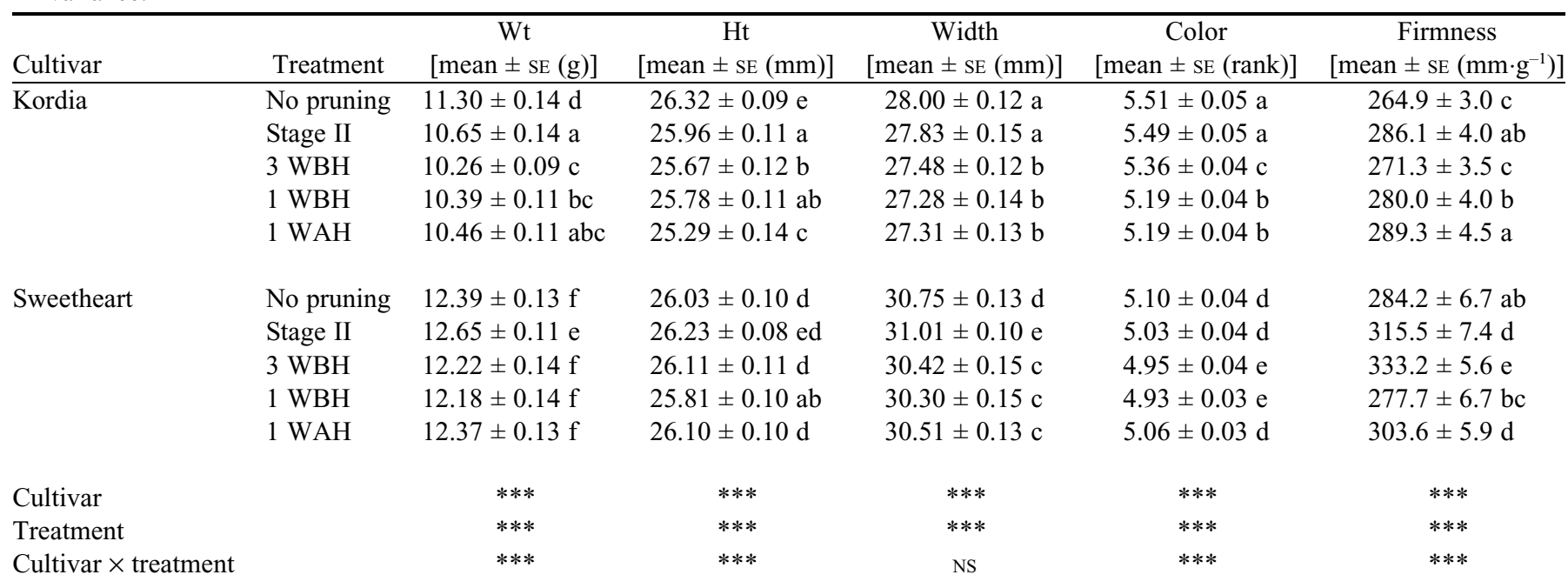

${ }^{\mathrm{z}}$ Harvest was conducted in Summer 2013 (the subsequent harvest season after application of the pruning treatments in season 2011-12). Treatment groups followed by the same letter did not differ statistically significantly from each other $(P>0.05)$.

$\mathrm{WBH}=$ weeks before harvest; $\mathrm{WAH}=$ weeks before harvest.

$* * * P<0.001 ; * * P<0.05 ; \mathrm{NS}=$ nonsignificant.

Table 4. Effect of cultivar (Kordia and Sweetheart) on bud non-structural carbohydrate concentrations under different croploads determined using analysis of variance. ${ }^{z}$

\begin{tabular}{|c|c|c|c|c|c|c|}
\hline & Fructose & Glucose & Sucrose & TSS & Starch & $\mathrm{NSC}$ \\
\hline & \multicolumn{6}{|c|}{$\left[\right.$ mean $\left.\pm \mathrm{SE}\left(\mathrm{mg} \cdot \mathrm{g}^{-1} \mathrm{DW}\right)\right]$} \\
\hline \multicolumn{7}{|l|}{ Winter } \\
\hline Kordia & $4.7 \pm 0.3$ & $2.8 \pm 0.1$ & $26.4 \pm 2.1$ & $33.8 \pm 2.5$ & $5.7 \pm 0.3$ & $39.5 \pm 2.6$ \\
\hline Cultivar & $* * *$ & $* * *$ & $* *$ & NS & NS & NS \\
\hline Treatment & $* *$ & NS & NS & NS & $* * *$ & $* *$ \\
\hline
\end{tabular}

${ }^{\mathrm{z} B u d}$ collections were conducted in southern Tasmania in winter (June 2012) from high- or low-cropping trees.

TSS $=$ total soluble sugars, expressed as a sum of fructose, glucose, and sucrose; NSC $=$ total non-structural carbohydrates, expressed as a sum of TSS and starch; DW = dry weight.

$* * * P<0.001 ; * * P<0.05 ;$ NS $=$ nonsignificant. 


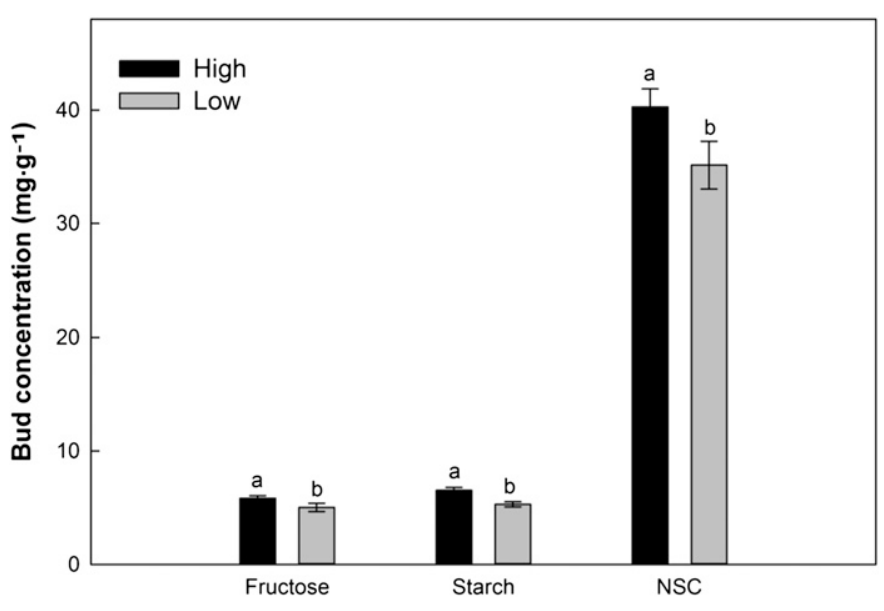

Fig. 4. Mean concentrations of fructose, starch, and total non-structural carbohydrate (NSC) concentration in buds of sweet cherry from trees with high (black bars) and low (light gray bars) cropload. Buds were collected from both cultivars (Kordia and Sweetheart) in winter (June 2012) in southern Tasmania. Values are means of 10 replicates $\pm \mathrm{SE}$. Treatment groups followed by the same letter did not differ statistically significantly $(P>0.05)$ from each other using Student's $t$ test.

had higher levels of sucrose than 'Sweetheart'. Although 'Kordia' had more potential sucrose to support bud burst than 'Sweetheart', the rate of bud burst in 'Kordia' was slower. A study by Measham et al. (2014) also determined that 'Kordia' had a prolonged MTB and a higher chill requirement. These observations potentially link time to complete bud burst with high levels of sucrose in buds during winter. This may explain the difference in bud burst between cultivars (Measham et al., 2014); however, a large-scale experiment involving many cultivars is required to provide conclusive results. The level of sucrose in the winter buds could be related to MTB [like during dormancy release, sucrose is used in buds to synthesize the sorbitol and raffinose that are required for bud burst (Marquat et al., 1999)]. This aligns with previous studies (Ben Mohamed et al., 2010; Ito et al., 2002) that found it was the capacity of buds to use carbohydrates rather than the absolute levels of carbohydrates in buds that affects bud growth rate. Ito et al. (2002) did not find a relationship between sugar content and bud growth in pear and suggested a greater role for catabolizing enzymes in progressing bud burst. Richardson et al. (2010) determined that the remobilization and supply of carbohydrates were essential in dormancy release of kiwifruit buds. We additionally found that trunk diameter was significantly correlated to the levels of SS in winter buds in 'Kordia'. This result may indicate that, for this cultivar at least, larger trees accumulate more NSC reserves, which can then be redistributed to sinks such as buds during periods of stress such as bud burst and that bud NSCs may vary closer to bud burst.

Fruit from both cultivars responded in a similar manner in the next season. In contrast to previous studies in sweet cherry trees (Kappel et al., 1997; Webster and Shepherd, 1984), pruning in one season significantly affected fruit size and quality at harvest the next season (Table 2). In both 'Kordia' and 'Sweetheart', early pruning (Stage II) during bud development resulted in bigger fruit the next season than when pruning occurred later in fruit development. This difference in fruit size would not have been a result of different croploads because there was only a weak relationship between bud or

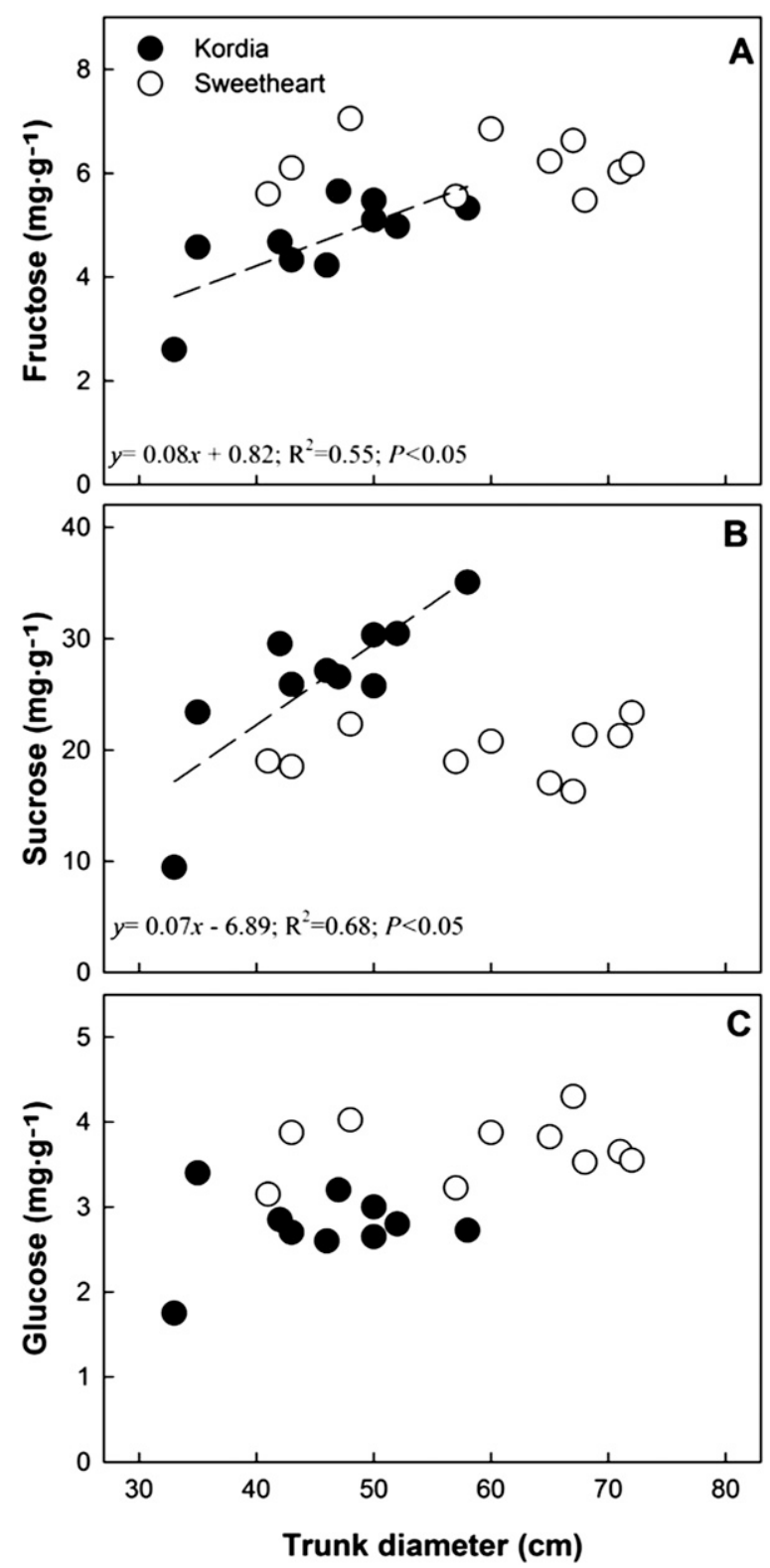

Fig. 5. Mean fructose (A), sucrose (B), and glucose (C) concentration in sweet cherry buds as a function of trunk diameter in two sweet cherry cultivars [Kordia (dashed line) and Sweetheart (solid line)] growing in southern Tasmania. Each point represents a mean of 10 samples.

flower numbers as a result of pruning treatments. Moreover, it was unlikely that loads were sufficient to induce a decrease in fruit size (Bound et al., 2013). Furthermore, Measham et al. (2013) showed that pruning at Stage II of fruit development negatively impacted the current season's fruit quality indicating a competitive interaction.

Fruit-fruit competition is known to impact the amount of photosynthate available to the surviving reproductive organs (Goldschmidt, 1999). In the present study, we found that high cropload resulted in higher NSCs accumulated in the winter buds than the low cropload. Greater sink strength (competitive ability to attract assimilates) exhorted by the higher number of fruits may explain the higher levels of carbohydrates in the buds. Fruit-bud competition is also implicated given the slightly lower bud sugar levels as bud numbers increased. 
This study demonstrated that although pruning was able to manipulate NSCs in buds within a few weeks, these changes were not sufficient to influence the rate of bud burst within a cultivar but did influence fruit quality in the next season. This indicates that sweet cherry fruit buds may be able to draw on carbohydrate reserves for initiating bud burst. However, bud quality and subsequent fruit quality may be impacted by carbohydrate allocation during the previous growing season. It confirms the importance of carbohydrate remobilization and management of stress for adequate carbohydrate reserves.

\section{Literature Cited}

Ayala, M. and G.A. Lang. 2008. ${ }^{13}$ C-Photoassimilate partitioning in sweet cherry on dwarfing rootstocks during fruit development. Acta Hort. 795:625-632.

Ben Mohamed, H., A.M. Vadel, J. Geuns, and H. Khemira. 2012. Carbohydrate changes during dormancy release in superior seedless grapevine cuttings following hydrogen cyanamide treatment. Sci. Hort. 140:19-25.

Ben Mohamed, H., A.M. Vadel, J.M.C. Geuns, and H. Khemira. 2010. Biochemical changes in dormant grapevine shoot tissues in response to chilling: Possible role in dormancy release. Sci. Hort. 124:440447.

Bonhomme, M., R. Rageau, A. Lacointe, and M. Gendraud. 2005. Influences of cold deprivation during dormancy on carbohydrate contents of vegetative and floral primordia and nearby structures of peach buds (Prunus persica L. Batch). Sci. Hort. 105:223-240.

Bound, S.A., D.C. Close, A.G. Quentin, P.F. Measham, and M.D. Whiting. 2013. Crop load and time of thinning interact to affect fruit quality in sweet cherry. J. Agr. Sci. 5:216-230.

Bustan, A., A. Avni, S. Lavee, I. Zipori, Y. Yeselson, A.A. Schaffer, J. Riov, and A. Dag. 2011. Role of carbohydrate reserves in yield production of intensively cultivated oil olive (Olea europaea L.) trees. Tree Physiol. 31:519-530.

Cerasoli, S., P. Maillard, A. Scartazza, E. Brugnoli, M.M. Chaves, and J.S. Pereira. 2004. Carbon and nitrogen winter storage and remobilisation during seasonal flush growth in two-year-old cork oak (Quercus suber L.) saplings. Ann. For. Sci. 61:721-729.

Clair-Maczulajtys, D., C. Sarthou, and G. Bory. 1994. Effects of pruning on carbohydrate distribution in the trunk of sweet cherry (Prunus avium L.). Sci. Hort. 59:61-67.

Costes, E., P.E. Lauri, and J.L. Regnard. 2006. Analyzing fruit tree architecture: Implications for tree management and fruit production. Hort. Rev. 32:1-61.

Daie, J. 1985. Carbohydrate partitioning and metabolism in crops. Hort. Rev. 7:69-108.

Dejong, T.M. and Y.L. Grossman. 1995. Quantifying sink and source limitations on dry matter partitioning to fruit growth in peach trees. Physiol. Plant. 95:437-443.

Essiamah, S. and W. Eschrich. 1985. Changes of starch content in the storage tissues of deciduous trees during winter and spring. IAWA Bul. 6:97-106.

Flore, J.A. and D.R. Layne. 1999. Photoassimilate production and distribution in cherry. HortScience 34:1015-1019.

Gaudillère, J.-P., A. Moing, and F. Carbonne. 1992. Vigour and nonstructural carbohydrates in young prune trees. Sci. Hort. 51:197-211.

Gent, M.P.N. and I. Seginer. 2012. A carbohydrate supply and demand model of vegetative growth: Response to temperature and light. Plant Cell Environ. 35:1274-1286.

Goldschmidt, E.E. 1999. Carbohydrate supply as a critical factor for citrus fruit development and productivity. HortScience 34:1020 1024.

Ito, A., H. Hayama, and Y. Kashimura. 2002. Sugar metabolism in buds during flower bud formation: A comparison of two japanese pear [Pyrus pyrifolia (Burm.) Nak.] cultivars possessing different flowering habits. Sci. Hort. 96:163-175.
Ito, A., D. Sakamoto, and T. Moriguchi. 2012. Carbohydrate metabolism and its possible roles in endodormancy transition in japanese pear. Sci. Hort. 144:187-194.

Kapp, C.J. 2008. Manipulation of the chilling requirement of sweet cherry trees. PhD diss., Univ. of Stellenbosch, Stellenbosch, South Africa.

Kappel, F., M. Bouthillier, and R. Brownlee. 1997. Summer pruning young Sweetheart sweet cherry trees affects yield and tree size. HortScience 32:1034-1036.

Keller, J.D. and W.H. Loescher. 1989. Nonstructural carbohydrate partitioning in perennial parts of sweet cherry. J. Amer. Soc. Hort. Sci. 114:969-975.

Klages, K., H. Donnison, J. Wünsche, and H. Boldingh. 2001. Diurnal changes in non-structural carbohydrates in leaves, phloem exudate and fruit in 'Braeburn' apple. Funct. Plant Biol. 28:131-139.

Kozlowski, T.T. 1992. Carbohydrate sources and sinks in woody plants. Bot. Rev. 58:107-222.

Lacointe, A., A. Kajji, F.-A. Daudet, P. Archer, J.-S. Frossard, B. Saint-Joanis, and M. Vandame. 1993. Mobilization of carbon reserves in young walnut trees. Acta Bot. Gallica 140:435-441.

Lang, G.A. 2001. Underlying principles of high density sweet cherry production. Acta Hort. 667:325-336.

Layne, D.R. and J.A. Flore. 1995. End-product inhibition of photosynthesis in Prunus cerasus L. in response to whole-plant sourcesink manipulation. J. Amer. Soc. Hort. Sci. 120:583-599.

Loescher, W.H., T. McCamant, and J.D. Keller. 1990. Carbohydrate reserves, translocation, and storage in woody plant roots. HortScience 25:274-281.

Marafon, A.C., I. Citadin, L. Amarante, F.G. Herter, and F.J. Hawerroth. 2011. Chilling privation during dormancy period and carbohydrate mobilization in japanese pear trees. Sci. Agr. 68:462468.

Marquat, C., M. Vandamme, M. Gendraud, and G. Pétel. 1999. Dormancy in vegetative buds of peach: Relation between carbohydrate absorption potentials and carbohydrate concentration in the bud during dormancy and its release. Sci. Hort. 79:151-162.

Maust, B.E., J.G. Williamson, and R.L. Darnell. 2000. Carbohydrate reserve concentrations and flower bud density effects on vegetative and reproductive development in southern highbush blueberry. J. Amer. Soc. Hort. Sci. 125:413-419.

Measham, P.F., S.A. Bound, A.J. Gracie, and S.J. Wilson. 2012. Crop load manipulation and fruit cracking in sweet cherry (Prunus avium L.). Adv. Hort. Sci. 26:25-31.

Measham, P.F., N. MacNair, A.G. Quentin, and S.A. Bound. 2013. To cut or not to cut: The role of extension growth in fruit quality. Intl. Soc. Hort. Sci. Proc. XII Intl. Cherry Symp., Spain, 23-27 June.

Measham, P.F., A.G. Quentin, and N. MacNair. 2014. Climate, winter chill and decision making in sweet cherry production. HortScience 49:1-6.

Pinkard, E.A. and C.L. Beadle. 1998. Aboveground biomass partitioning and crown architecture of Eucalyptus nitens following green pruning. Can. J. For. Res. 28:1419-1428.

Proebsting, E.L. and H.H. Mills. 1981. Effects of season and crop load on maturity characteristics of 'Bing' cherry. J. Amer. Soc. Hort. Sci. 106:144-146.

Rady, M.M. and M.A. Seif El-Yazal. 2013. Response of 'Anna' apple dormant buds and carbohydrate metabolism during floral bud break to onion extract. Sci. Hort. 155:78-84.

Richardson, A.C., E.F. Walton, J.S. Meekings, and H.L. Boldingh. 2010. Carbohydrate changes in kiwifruit buds during the onset and release from dormancy. Sci. Hort. 124:463-468.

Roper, T.R., J.D. Keller, W.H. Loescher, and C.R. Rom. 1988. Photosynthesis and carbohydrate partitioning in sweet cherry: Fruiting effects. Physiol. Plant. 72:42-47.

Roussos, P.A., V. Sefferou, N.-K. Denaxa, E. Tsantili, and V. Stathis. 2011. Apricot (Prunus armeniaca L.) fruit quality attributes and phytochemicals under different crop load. Sci. Hort. 129:472-478. 
Seginer, I. and M. Gent. 2012. Vegetative growth response to light and temperature, interpreted by carbohydrate-pool dynamics. Acta Hort. 956:231-238.

Smith, M.W., C.T. Rohla, and N.O. Maness. 2007. Correlations of crop load and return bloom with root and shoot concentrations of potassium, nitrogen, and nonstructural carbohydrates in pecan. J. Amer. Soc. Hort. Sci. 132:44-51.

Usenik, V., J. Fabcic, and F. Stampar. 2008. Sugars, organic acids, phenolic composition and antioxidant activity of sweet cherry (Prunus avium L.). Food Chem. 107:185-192.
Vasudevan, L., T.K. Wolf, G.G. Welbaum, and M.E. Wisniewski. 1998. Reductions in bud carbohydrates are associated with grapevine bud necrosis. Vitis 37:189-190.

Vitasse, Y., C. François, N. Delpierre, E. Dufrêne, A. Kremer, I. Chuine, and S. Delzon. 2011. Assessing the effects of climate change on the phenology of European temperate trees. Agr. For. Meteorol. 151:969-980.

Webster, A.D. and U.M. Shepherd. 1984. The effects of summer shoot tipping and rootstock on the growth, floral bud production, yield and fruit quality of young sweet cherries. J. Hort. Sci. 451:643-652. 